\begin{tabular}{|c|c|c|}
\hline & $\begin{array}{l}\text { INTERNATIONAL JOURNAL OF } \\
\text { POLITICAL STUDIES }\end{array}$ & $\begin{array}{l}\text { INTERATIONAL } \\
\text { JOUUNALF } \\
\text { POUTICALSTUDES }\end{array}$ \\
\hline 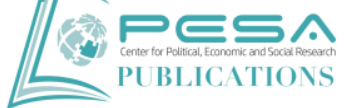 & $\begin{array}{c}\text { ULUSLARARASI } \\
\text { POLITIK ARASTIRMALAR DERGISİ }\end{array}$ & \\
\hline & $\begin{array}{cc}\text { April 2019, Vol:5, Issue:1 } & \text { Nisan 2019, Cilt:5, Sayn } 1 \\
\text { e-ISSN: } 2149-8539 & \text { p-ISSN: } 2528-9969\end{array}$ & \\
\hline
\end{tabular}

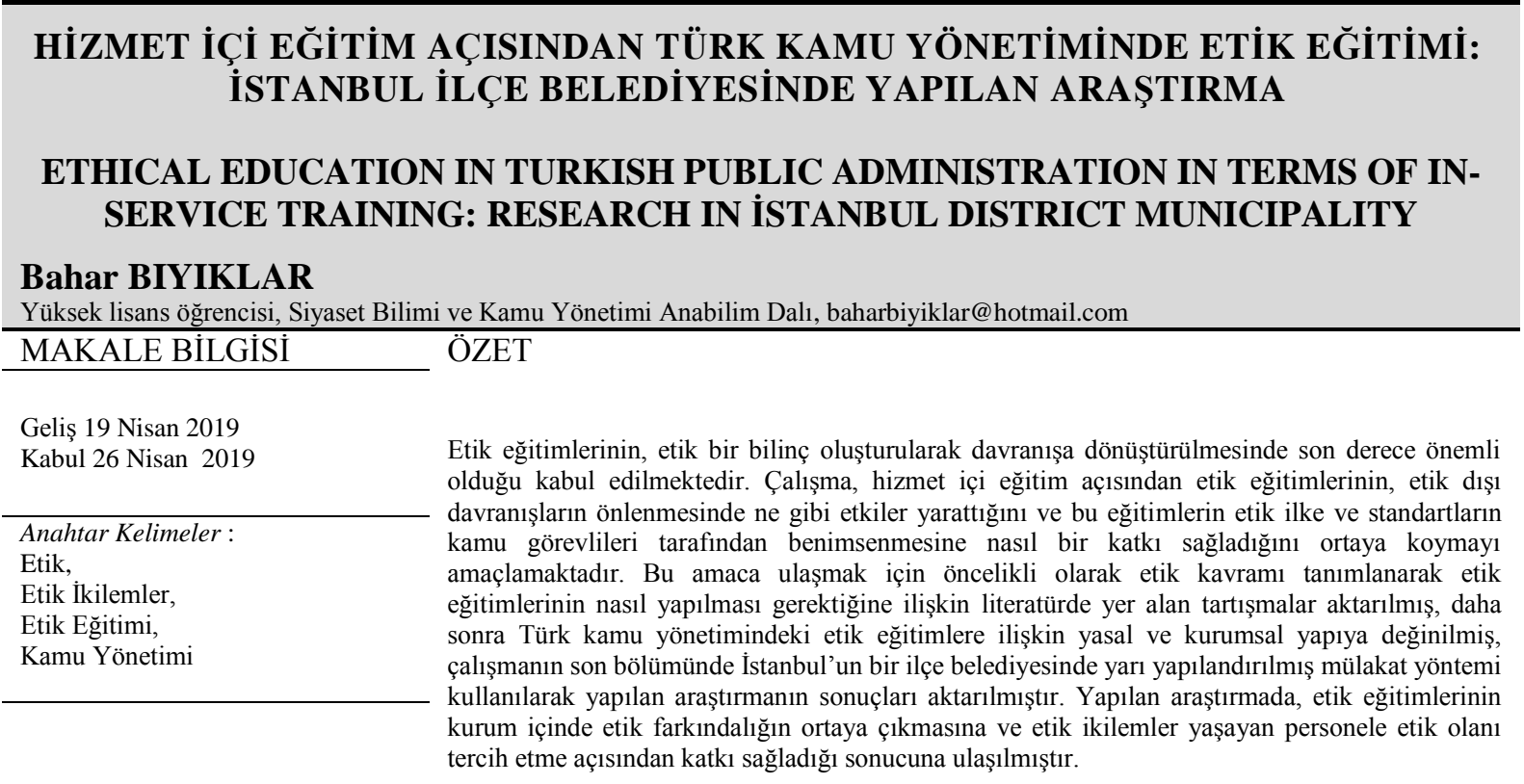

(C) 2019 PESA All rights reserved

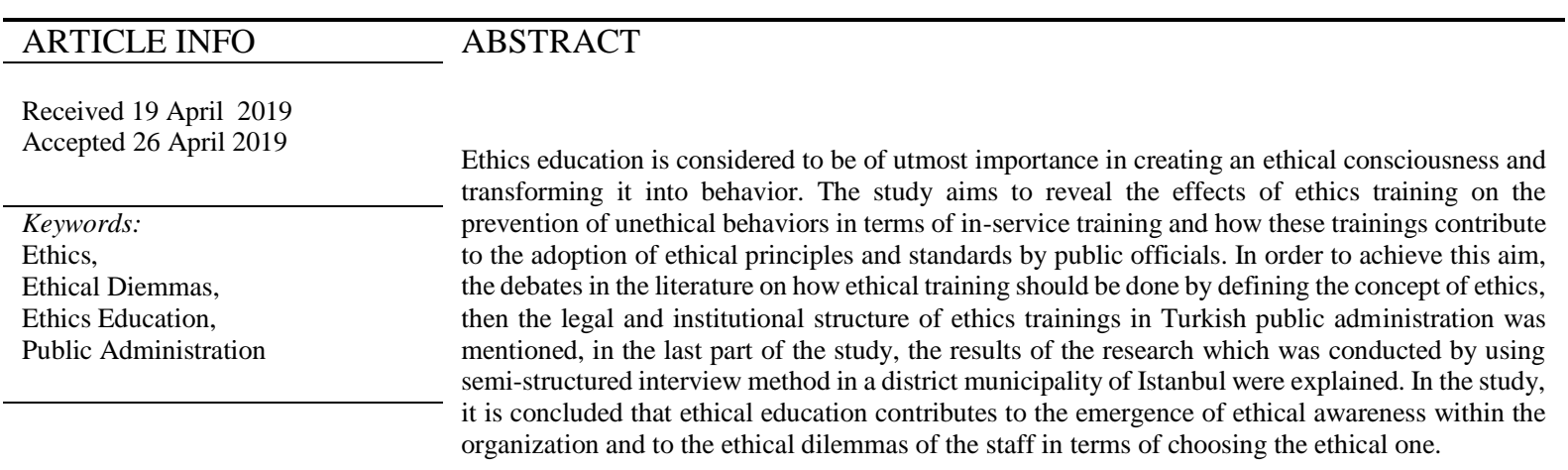

\title{
Giriş
}

Kökeninin Antik Yunan'a kadar götürebileceğimiz “etik” kavramı günümüzde sıkça kullanılmaktadır. Etik, bir kişiye ne yapmasını ya da ne yapmamasını gösteren ilke ve değerlerdir. Dolayısıyla bir toplumda var olan yaşam anlayışından kaynaklanan, iyi olduğu düşünülen, davranış, kural ve ilkelerin bütünü etik kavramının karşılığı olarak tanımlanabilir. Etik 1970’ lerden sonra daha fazla gündeme 
gelen bir kavram olmakla birlikte, özellikle Amerika'da yapılan çalışmalarda Watergate ${ }^{1}$ gibi skandalların ortaya çıkmasıyla etik bilincin oluşturulmasının önem kazandığı görülmektedir. Ancak etik bilincin oluşturulması, etik eğitimine olan ihtiyacı da beraberinde getirmiştir. Çünkü etik eğitimi, kamu görevlilerinin davranışlarına odaklanarak, sorumluluk bilincinin oluşmasında, kamu gücünün kamu yararına kullanılmasında, kamuda etik bilincin oluşturulmasında, etik dışı faaliyetlerin önüne geçilmesinde en önemli rehber olarak gösterilebilir.

Türkiye'de etik eğitimi konusunda yasal ve kurumsal düzenlemelere gidilmiştir. Etik eğitimi, Kamu Görevlileri Etik Davranış İlkeleri ile Başvuru Usul ve Esasları Hakkında Yönetmelik çerçevesinde, kamuda etik kültürünü yerleştirmek ve kamu görevlilerinin görevlerini yerine getirirken uymaları gereken etik davranışların oluşturulmasında önemli bir yere sahiptir.

Makalenin temel amacı, etik eğitimlerinin kurum içinde etik bilincin oluşturulmasına olan etkisini ortaya koymaya çalışmaktadır. Bu çerçevede öncelikle etik kavramı, kamu yönetiminde etik, kamu yönetiminde etik ikilemler, etik eğitimi, Türk kamu yönetiminde etik eğitimi ele alınarak, daha sonra İstanbul ilçe belediyesinde, yarı yapılandırılmış mülakat yöntemi kullanılarak yapılan çalışmanın sonuçları aktarılacaktır. Etik eğitimin, kurum içinde etik bilincin oluşmasına ne yönde bir etkisinin olduğu konusundaki literatürdeki eksikliğin giderilmesi planlanmaktadır.

\section{Etik Kavramı}

Felsefenin bir alt disiplini olan etik, insan için doğru ve yanlışın sistematik olarak değerlendirilerek insan ve toplum için ideal olanın araştırıldığı bir çabadır (Aydın, 2016a: 45). Bugün etik konusunda aynı eylemler ve uygulamalar arasında bağlantı kurularak, iyilik, dürüstlük, adalet, erdem, suç ve kabadayılık gibi kavramlardan oluşan çerçeveden yola çıkılmakta ve toplumsal uzlaşma ile genel iyi ve doğru davranış kuralları belirlenmektedir (Haynes, 2014: 23).

Etik, geçmişte, günümüzde ve gelecekte insanların eylemlerinde ya da ilişkilerinde ortaya çıkan tutum ve davranışların iyi-kötü, doğru-yanlış bağlamında değerlendirilmesinde ve gerekçelendirmesinde rol oynayan dünyanın her yerinde geçerli olan değer, ilke ve kurallar bütünüdür (Aydın, 2016a: 46-47; Yatkın, 2015: 14). Burada söz konusu olan eylemlerdir. Kişiyi eyleme götüren etkenler, eylemin koşulları, sonuçları, doğruluğu-yanlışlığı etiğin alanını oluşturmaktadır (Tepe, 2011: 16).

Etik konusunda farklı tanımlamalar karşımıza çıkmaktadır. Öncelikle sözlük anlamına göre etik, ahlak ilkeleri üzerine temellenerek doğru davranış1 incelemektedir (TÜSİAD, 2005: 49). Etik ahlakı, görev ve zorunluluk ile iyi ve kötünün ne olduğuyla ilgilenmektedir (Starc, 2017: 48). Genel anlamda ise, ahlak üzerine düşünme etkinliği olarak tanımlanmaktadır (Cevizci, 2016: 17).

Etik, ahlak felsefesi olarak da anılmaktadır. Çünkü "belirli bir ahlak ya da ahlaklılık üzerinde çalışan, ahlaksal sorunları ve yargıları felsefeyle ele alan kişi etik veya ahlak felsefesi yapmaktadır. Üzerinde konuşulan şey belirli bir ahlak, ahlak kurumu veya genel olarak ahlak ise, onun felsefi çözümlemesinin bilgisi de ahlak felsefesi olacaktır" (Tepe, 2011: 56). Dolayısıyla çeşitli tanımlardan da anlaşılacağı

\footnotetext{
${ }^{1}$ Watergate skandalı 1972-1974 yılları arasında Amerika Birleşik Devlet'inin başkenti Washington'da gelişen ve Başkan Richard Nixon'un istifa etmesi ile sonuçlanan siyasi bir skandaldır. Yeniden başkan seçilmek isteyen Cumhuriyetçi Nixon'un kadroları tarafından 1972 seçimleri için Başkanı Yeniden Seçtirme Komitesi kurulur. Tam seçim günü Watergate Otel ve İş Merkezi kompleksin de yer alan Demokratik Milli Komitesi'ne hırsızlık amaçlı girdiği sanılan 5 kişi tutuklanmıştır. Hırsız sanılan bu 5 kişinin asıl amacı, Demokratik Partiye bağlı komitenin gizli bilgilerini fotoğraflamak ve ofise dinleme cihazı yerleştirerek konuşmalardan haberdar olmaktı. Soruşturmanın derinleşmesi ve medyanın da yer almasıyla birlikte bu 5 kişinin harcamalarının Başkanı Yeniden Seçtirme Komitesi tarafından karşılandığı görülür. Dolayısıyla bu seçim kampanyası bağış toplama işlevini aşarak, Amerikan tarihinin aydınlatılabilmiş en büyük yolsuzluk skandalı olur (http://www.gazetebilkent.com).
} 
üzere günlük dilde de çoğu zaman ahlak kavramıyla karıştırılan etik kavramının tam olarak anlaşılabilmesi için ahlak ve etik arasında bir ayrıma gitmek gereklidir.

Ahlak, geçmişten günümüze var olan toplumlar tarafından bireylerin birbirleriyle olan davranışlarını düzenlemek için kullanılan normlar, kurallar ve değerlerden oluşmaktadır. Burada söz konusu olan gelenekselleşmiş kural ve değerlerdir. Etik ise, ahlak ve ahlaklılık üzerine felsefi bir sorgulamadır. Ahlak yerel olduğu yerde etik genel veya evrenseldir. Bireyler kural ve değerler üzerine düşünmeye ve sorgulamaya başladığı noktada ahlaktan etiğe geçme durumundadır (Cevizci, 2016: 17).

TDK' ya göre etik, ahlaki, ahlakla ilgili olan anlamındadır. Ancak ettiğin yönelttiği sorular belirli somut durumlara ilişkin olmadıkları için ahlak sorularından ayrılmaktadırlar. Diğer bir deyişle, etik sorular doğrudan ahlaki norm ve değerlerin genelini bağlayan nitelikteki koşulları araştırarak ahlaki eylemi konu olarak belirledikleri için ahlak sorularından ayrılmaktadırlar. Bu kavramsal farklılıktan etik düşüncelerin doğrudan ahlaki olmadığını, ancak ahlaka ilişkin soruna gösterilen ilgi olduğunu çıkarmak mümkündür. Dolayısıyla ahlaki olan her ahlaki düşüncenin etik konusu olamayacağı, ancak etik sorunlarına dönüştürülebileceği söylenebilir (Pieper, 2012: 33).

\section{Kamu Yönetiminde Etik}

Kamu görevlilerinin kamusal hizmetleri yerine getirirken nasıl davranması gerektiği kamu yönetiminde etiğin konusudur. $\mathrm{Bu}$ yönetim faaliyeti içerisinde hem yönetilenlerin tutum ve davranışları hem de hizmeti sunan görevlilerin davranışları devlet ve kamu hizmetinden yararlananlar açısından önemlidir. Hizmetler yerine getirilirken sergilenen davranışlar kamu bürokrasisinin ne kadar sağlıklı ve güvenli bir şekilde işlediğinin de göstergesidir (Önen ve Yıldırım, 2014: 112).

Devlete ve kurumlarına karşı güven sağlanması ve bunun korunmasının en önemli unsurlarından biri etik bir yönetimdir. Çünkü etik, kamu yönetiminde eylem ve işlemlerin sınandığı bir temel oluşturarak, toplum çıkarlarının korunduğu ve işlerin doğru olarak yapıldığına dair kamuoyunda bir güven sağlar (Eryılmaz, 2012: 406). Dolayısıyla kamu yönetimindeki etik dışı faaliyetler hem hukuk sistemine hem de devlete karşı olan güveni zayıflatır. Ayrıca kamu yönetiminde etiğin en önemli özelliklerinden birisi sosyal sorumluluk bilincidir. Sosyal sorumluluk bilinci, kamu görevlilerinin topluma karşı sadakat ve bağlılığını oluşturmaktadır. Çünkü kamu gücünü toplum menfaatine öncelik vererek, kişisel çıkarları için kullanmaması her kamu görevlisinin görevidir (Yüksel, 2010: 38).

Kamu görevlileri, kamu görevini yerine getirirken, çalıştıkları kurum veya kuruluşun ulusal çıkarları, toplumun refahı ve hizmet idealleri çerçevesinde belirlenen amaç ve misyona bağlı kalırlar (Alıcı, t.y: 67). Böylece kamu görevlilerinin bir yandan tüm meslekler için ortak ve geçerli olan meslek etiği ilkelerine uygun davranması beklenirken, bir yandan da kamu için çalışma ve kamu kaynaklarını adil kullanma konusunda etik davranmaları beklenir (Aydın, 2016b: 161).

Kamu yönetimi etiği, kamu görevlileri açısından bir yol gösterici görevi görür. Kamu görevlilerine iyi davranışta bulunma ve kötü davranıştan kaçınma konusunda rehberlik eder. Bu da devlete ve kamu görevlilerine olan güveni arttırarak, yönetimin meşruiyetinin gelişmesini sağlar ve halk-devlet bütünleşmesine katkı sağlamaktadır (Şen, 2012: 10).

\section{Kamu Yönetiminde Etik İkilemler}

Kamu görevlilerinin içinde bulundukları, karar vermelerinin karmaşık ve bir hayli zor olduğu ve bir olayın birbiri ile ters düşen iki tarafında da tartışılabilir doğrularının olması durumunda ortaya çıkan çelişkiler etik yargılardan kaynaklanıyorsa etik ikilem olarak tanımlanmaktadır (Kutlu, 2008: 150).

Kamu görevlileri, kamu hizmetlerini yerine getirirken, her biri farklı değere sahip seçenekler arasında tercih yaparken zorlanmakta, diğer bir ifade ile neyin etik ve neyin etik dış1 olduğu konusunda tereddüt 
yaşayarak etik ikilemlerle karşı karşıya kalabilmektedirler. Ancak kamu görevlisinin bu seçimi yasalara uygun olsa bile, ahlakı açıdan iyi ve doğru olmayabilir (Şen, 2005: 361).

Kamu görevlileri kamu hizmetini yerine getirirken sıklıkla etik ikilemlerle karşı karşıya kalmaktadır. Bu ikilemler dört grupta incelenmektedir. Bunlar (Şen, 2012: 15-17):

1. Kamu görevlilerinin önlerindeki seçeneklerden hiçbiri tam manasıyla tatmin edici olmayabilir. Fakat kamu görevlileri tarafından bunların içinden diğerlerine göre daha iyi olanın seçilmesi durumudur.

2. Kamu görevlisi en iyiler arasından bir seçim yapmak durumundadır. Burada söz konusu olan seçeneklerin birden fazlası veya tamamı iyidir ve birisinin seçilmesi diğerlerinden vazgeçilmesi demektir.

3. Farklı kişi ve gruplar üzerinde farklı etki ve sonuçlar ortaya çıkması söz konusu olan bir kararın verilmesidir.

4. Kamu görevlileri verecekleri kararın sonucundan kendilerinin veya yakınlarının olumlu ya da olumsuz veya dolaylı ya da dolaysız etkilenmeleri halidir. Burada çıkar çatışması söz konusu olmaktadır. Çünkü kamu görevlisinin bireysel çıkarları ile genel anlamda kamu çıkarları çelişmektedir. Böyle bir durumda da kişinin kendi çıkarının tersine bir karar vermesi zor olacağından, ilgili kişinin karar verme sürecine katılmaması en doğrusudur.

Kamu personelinin karşı karşıya kaldığı bu etik ikilemler karşısında nasıl hareket edeceği noktasında etik ilke ve değerler rehberlik eder. Ancak bu noktada çok önemli bir sorun ortaya çıkmaktadır. Kamu görevlileri açısından bu etik ilke ve değerin ne derecede rehber olarak alındığıdır. Bu noktada, etik eğitimlerinin etiğe dayalı bir yapının kurulması için son derece önemli olduğu düşünülmektedir.

\section{Etik Eğitimi}

Eğitim yaşam boyu süren bir süreçtir. Bu süreçte her insan sosyal ve fiziksel bir çevre içerisinde yaşamaktadır. Yaşam boyu devam eden bir davranış değiştirme süreci olarak da tanımlanan eğitim, sosyal ve fiziksel çevre içerisinde yani hayatımızın her alanında yer almaktadır. Aynı zamanda bireyler hayatın içinde attığı her adımda ve yaptığı her eylemde etiksel bir tutum sergilemek zorundadır (Ilgaz ve Bilgili, 2006: 201). Çünkü Pieper’e göre, “İnsan doğası gereği ahlaki bir varlık değildir, ahlaki olarak eğitilmesi gerekir". Dolayısıyla ahlakilik ve eğitimin birbirlerini karşılıklı tamamladıkları ve etiğin de eğitimle bir yakınlığından söz edilebilir (Pieper, 2012: 112).

1970'lerden itibaren kamu yönetiminde etik, sıkça karşılaşılan bir konu olarak ortaya çıkmaya başlamıştır. Bu konuya paralel etik eğitiminin de önemi artmış ve bu kapsamda çalışmalar yapılmaya başlanmıştır. ABD' de Watergate skandallarının ortaya çıkması bu çalışmaların temelini oluşturmuş ve kamu yönetiminde etik bilincin oluşturulması ve yerleştirilmesinin öne çıkması etik eğitime olan ihtiyacı da gündeme getirmiştir. Bu ihtiyaç bazı temel varsayımların kabulüne yol açmıştır. Bu varsayımlar: Kamu kurumları kamu yararına çalışmakta olup kamu hizmetleri etik davranmayı gerektirir. Kamu çalışanları, dürüstlük, samimiyet, tarafsızlık, açı sözlülük, adaletli davranma gibi önemli ve gerekli toplumsal değer yargılarına sahip olmak zorundadırlar. Kamu çalışanlarının işe alınmasında liyakat ilkesi esas alınmalıdır. Kamu çalışanları, görevlerini yerine getirirken sadakat, etkinlik ve ekonomikliği ön planda tutmalıdır. Kamu çalışanları, politik yansızlığa özen göstermelidir. Bu varsayımlardan yola çıkarak ABD'de etik eğitimi üzerine yapılan çalışmalarla etik eğitimin genel bir çerçevesi oluşturulmaya başlanmıştır (Demiral ve Demiral, 2007: 276).

Günümüzde etiğin, sadece bir teori alanı olmaktan çıkarılarak pratik hale getirilmesinde ve bir davranışa dönüştürülmesinde ki en önemli araçlardan birinin eğitim olduğu açıktır. Gerek hizmet öncesi gerekse 
hizmet içi eğitimler ile hem kamu kesiminde hem de toplumda etik sorunları anlama, uygun tepkiler verme ve bireyleri iyi ve doğru davranış konusunda kendi kendilerini yargılayabilecek konuma getirme amaçlanmaktadır. Çünkü yönetim ve insan birlikte anlam ifade etmektedir. Şöyle ki çağdaş ve mükemmel hukuksal, kurumsal düzenlemeler ve denetim araçlarının var olması, etik değerleri anlamamış ve benimsememiş insanlar oldukça hiçbir anlam ifade etmeyecek ve işlevi olmayacaktır. Dolayısıyla kamu görevlilerinin pratiğe yönelik etik eğitimi almaları son derece önemlidir (Nohutçu, 2004: 407). Uluslararası kuruluşların kamu yönetiminde etik ilkelerin hayata geçirilmesinde en önemli unsurlardan birinin eğitim olduğu belirtilmektedir (TÜSİAD, 2003: 102).

Kamu personeli, görevleri, yetkileri ve sorumlulukları açıkça tanımlanmış ve bilgilendirilmiş olsa dahi, içinde yer aldığı süreçte çeşitli durumlarla karşı karşıya kalabilmektedir. Bazen özel hayattan gelen kişisel ilişkiler, bazen siyasal baskılar, bazen ikilemler ve bazen de gelecek endişeleri bireyleri hizmetleri esnasında etik dışı davranmaya itebilmektedir (Gökdayı, 1998: 44). Kamu personeli bu gibi durumlarda etik konularında savunmasız kalabilmektedir. Çünkü etik ömür boyu süren bir aşı değildir. İnsanlar unutabilir, iş değişimleri yaşanabilir, terfiler olabilir ve yönetmelik ve kanunlar değişebilir. Böyle durumlarda düzenli etik eğitimleri önemli sistematik bileşen görevi görmektedir (Menzel, 2001: 358; Lewis ve Gilman: 2005: 203). Bu yüzden etik eğitimleri, kamu hizmetleri için temel olmalı ve temel bir ders olarak yerini almalıdır. Aynı zamanda mesleğin alt kademelerinden entegre edilmeye başlanmalı ve sürekli hale getirilmelidir (Ekins, 1998: 45). Çünkü hem daha verimli bir hükümet hem de liyakata dayalı bir kamu hizmeti sistemi kurulması etiğin normatif içeriği ile değil, kamu hizmetinde düzenli ve sürekli bir etik eğitimi ile sağlanabilir (Cooper, 2001: 3).

Kamu görevlilerine verilen etik eğitimi etik kod ve davranışlarını işlevsel hale getirmektedir (TÜSİAD, 2005: 140). Etik eğitimi, eğitimlerin içerikleri farklı olmakla birlikte genellikle 2 şekilde karşımıza çıkmaktadır. Bunlar "hizmet içi eğitimler" ve "hizmet öncesi eğitimler" dir. Hizmet içi eğitimler, "genel eğitim" ya da "hazırlayıcı eğitim" olarak da adlandırılmaktadır. Personelin hizmet öncesinde okullarda ve üniversitelerde genel ve mesleki yönden eğitilmesidir (Eryılmaz, 2012: 355). Hizmet öncesi eğitim ise, kişinin hizmete alındıktan sonra ya da hizmete alınırken hizmetin çeşitli aşamalarında mesleğin etik değerleri yönünden yetiştirilmesi olarak tanımlanabilir (Aydın, 2016b: 204). Hizmet içi eğitimler uzun yıllardır var olduğu bilinen eğitimlerdi. Ancak bir maliyet unsuru olarak görülmekte ve bu yüzden yapılmamaktaydı. 2000'li yıllarla birlikte kamu yönetiminde yapılan reformlarla önemi artmıştır.

Etik eğitimlerinde son zamanlarda öne çıkan konu ise farkındalık yaratmak olmuştur. Çünkü etik eğitimlerinin bireylerde karşılaşılan etik sorunları anlama, uygun tepkileri gösterme ve gereken şekilde davranma konusunda bilinçlendirmek en önemli hedeflerinden biri olarak gösterilebilir. Bu nedenle etik eğitiminin bir teoriden çok bilinçlenme düzeyini harekete geçirecek bir farkındalık yaratması asıl amaç olmalıdır. (Aydın, 2016a: 226)

Etik davranışın ortaya çıkmasında etik eğitimlerinde üzerinde durulması gereken dört farklı psikolojik süreçten bahsedilebilir. Bunlar "etik duyarlılık", "etik muhakeme", "etik bağl1lık" ve "etik kararlılık" tır. Etik duyarlılık, Bir durum veya olayda var olan etik sorun ya da ikilemleri fark edebilme yeteneğidir. Etik muhakeme, bireyin karşı karşıya kaldığı etik ikilemler ve sorunlarla ilgili uygun çözümleri bulmada kendi kendini sorgulama ve düşünme sürecidir. Etik bağlllık, karşı karşıya kalınan bir etik ikilem durumunda bireyin etik olanı tercih etmesidir. Etik kararlılık ise, kişinin güçlü bir karakter yapısı sergileyerek verdiği kararların arkasında durmasıdır. Ancak dikkat edilmesi gereken nokta etik bağl1lık ile etik kararlılığın birbiriyle karıştırılmamasıdır. Çünkü kişiler bazen cazip geldiği için ya da bir baskı durumuyla karşı karşıya kaldıkları için etik dışı davranabilir. Dolayısıyla etik kararlılığı veya bağlılığ1 yoktur. (Pimple'den aktaran, Aydın, 2016a: 226-227). Bu dört psikolojik sürecin bireylerde oluşturulması etik davranışın oluşturulması açısından önemli olduğu söylenebilir. Çünkü etik eğitimleri bu süreçler sayesinde bir teori olmaktan çıkıp bir davranış halini almaktadır.

\section{Türk Kamu Yönetiminde Etik Eğitimi}


Tüm dünya da var olduğu kabul edilen etik dışı faaliyetler ve yolsuzlukların Türk tarihine bakıldığında da çok eskilere dayandığı söylenebilir. Osmanlı devleti dönemlerine bakıldığında memur atamalarında yaygın olan rüşvetin, çöküşü hazırlayan en önemli etkenlerden biri olduğu görülmektedir. 16. yüzyıla kadar devlet, güçlü ve düzenli memur kadrosuna ve idare örgütüne sahip iken, 16. yüzy1ldan sonra Osmanlı devletinde bozulan idari sistem ile birlikte mali sistem de bozulma başlamış ve devlet yavaş yavaş otoritesini kaybetmiştir. Dolayısıyla yolsuzluk ve rüşvet için uygun bir ortam oluşmaya başlamıştır. Oluşan bu ortamın dar gelirli kamu yöneticilerini de etkilemesi sonucu yönetim ve halk arasındaki ilişkilerinde rüşvet gittikçe yaygınlaşmış ve geleneksel bir hal almıştır (Bayar, 1979: 46). Tanzimat dönemi ile birlikte bir takım önlemler alınmış fakat sonucunda başarılı olunamamış ve Osmanlı devletinin çöküşüne kadar yolsuzluk ve rüşvet devam etmiştir. Cumhuriyet dönemine gelindiğinde, 1946 çok partili demokrasiyi takiben yolsuzluk söylentileri eksik olmamıştır. Öyle ki kamu yönetimi, bürokrasi ve iktidar parti arasında bir mücadele alanına dönüşmüştür. 1960'ların ikinci yarısından itibaren, özellikle 1970'lerde artan bürokrasinin siyasallaşması sürecinde "siyasal kayırmacılık" ve "nepotizm" yaygınlaşmıştır. 1980'lerde de gittikçe yaygınlaşan yolsuzluk ve rüşvet, 1990'larda da artmaya devam etmiş, yolsuzluk ve rüşvet kamu yönetimin bir parçası konumuna gelmiştir. Bu dönemde artık kamu yönetimindeki etik dışı faaliyetlere halkın tepkisi artmaya başlamışırı (TÜSİAD, 2005: 87-88).

Türk kamu yönetiminde etik dışı faaliyetlerin yaygınlaşmasında temel nedenler aşağıdaki şekilde belirtilmektedir (TUSIAAD, 2005: 24);

- Kamu'da hukuk devleti ilkesinin yerleşmemiş olması,

- Kamuda etik kültürünün yerleşmemiş olması,

- Bürokrasinin merkeziyetçi ve statükocu bir yapı göstermesi,

- Siyasilerin bürokratik yapı üzerindeki etkisi,

- Takdir yetkisinin keyfi kullanılması,

- Bürokratik hizmetlerin kalitesi

- Kamu görevlilerinin kamu hizmetine adanmışılı̆ııda yetersizlik,

- Bürokratik işlemlerdeki kuralların çokluğu ve karmaşıklığı,

- İdari usul eksikliği,

- Kamuda istihdam sorunları,

- Kamu yönetiminde saydamlık eksikliği,

- Kamu yönetiminde denetim yetersizliği,

- Ekonomik nedenler,

- Eğitim eksikliği,

- Medya ve sivil toplumun etkinliğinin az oluşu,

- Bürokratik ayrıcalıklar.

Kamu yönetim sürecinde alınan kararlarda, yapılan uygulamalarda, eylem ve işlemlerde uzak durulması gereken davranışlar etik dışı davranışlar olarak tanımlanabilir. Günümüzde genel olarak etik dış1 davranışlar yolsuzluk ya da yozlaşma olarak tanımlanmaktadır (Özsemerci, 2005: 4). Türkiye, kamuda etik dışı faaliyetler konusunda Uluslar arası Şeffaflık Örgütü (TI)' nün her yıl yayınladığı yolsuzluk algı 
endeksinde Türkiye 2017 sonuçlarında diğer yıla göre 6 basamak gerileyerek 180 ülke arasında 81 . sırada yer almıştır. Endekste Türkiye, Avrupa Birliği ülkeleri arasında ise sonuncu sıradadır (www.seffaflik.org).

Türkiye'de yolsuzluk ile ortaya çıkan çeşitli sorunlar etik ve etik alt yapının oluşturulması ve buna bağlı önemi artan etik eğitimi konusunda da çeşitli düzenlemeler yapılmasını gerekli kılmıştır. Buna bağlı oluşturulan 2004 tarihli 5176 sayılı Kamu Görevlileri Etik Kurulunun Kurulması ve Kamu Görevlileri Etik Davranış İlkeleri ile Başvuru Usul ve Esasları Hakkında Yönetmelik, Türk kamu yönetiminde etik ve etik eğitimi konusunda yapılmış önemli düzenlemelerdir. Türkiye'de etik eğitimi konusuna Kamu Görevlileri Etik Davranış İlkeleri ile Başvuru Usul ve Esasları Hakkında Yönetmeliğin 25. maddesin de yer verilmiştir.

Türkiye' de etik eğitimi konusunda en yetkili olan birim Kamu Görevlileri Etik Kurulu'dur. Etik Kurulu, kamu görevlilerinin görevlerini yerine getirdiği esnada uymaları gereken etik davranış ilkelerini belirlemek, etik davranış ilkelerinin ihlali halinde gerekli inceleme ve araştırma yapmak, yapılan araştırmanın sonucunu ilgili makamlara bildirmek, kamuda etik kültürü oluşturmak için çalışmalar yapmak ya da yaptırmak ve destek olmakla görevlidir (5176, md.3). Ayrıca Etik Kurulu etik eğitim vermekle birlikte kamuda etik kültürünü yerleştirmek ve etik bilinci yaygınlaştırmak amacıyla panel ve sempozyumlar gerçekleştirmiştir. Kamu kurum ve kuruluşlarında etik farkındalığ 1 arttırmaya yönelik çeşitli afişler ve posterler çıkarmakta ve kitaplar, makaleler, akademik tezler, yargı, eğitim, sağlık, mühendislik, emniyet, iş etiği ve bankacılık üzerine de meslek etiği yayınlamaktadır (www.etik.gov.tr).

Kurul kamuda etik kültürünü yerleştirmek amacıyla çalışmalar yapmak ya da yaptırmak, yapılan çalışmalara destek olmak ve etik uygulamaları denetlemek için 2008 yılından itibaren her yıl 25 Mayıs günü ülke genelinde "Etik Günü", aynı günün yer aldığı hafta ise "Etik Haftası" olarak kabul etmiştir (www.etik.gov.tr, 2016)

\section{6. İstanbul İlçe Belediyesinde Yapılan Araştırma}

\subsection{Araştırmanın Amacı}

Türkiye' de 2004 yılında çıkarılan 5176 sayılı Yasa Türk kamu yönetimi açısından oldukça önemlidir. Ancak etik konusunda sadece yasal düzenlemeler yapmak yeterli değildir. Etik ilke ve değerlerin kamu personeli tarafından içselleştirilmesi gerekmektedir. Araştırmanın amacı; hizmet içi eğitim bağlamında verilen etik eğitimlerinin, etik ilke ve değerlerin benimsenmesi ve kurum kültürünün oluşmasına nasıl bir etki yaptığına ilişkin, etik eğitimi alanların değerlendirmelerini ortaya koymaktır.

\subsection{Araştırmanın Evren ve Örneklemi}

Araştırmanın evreni İstanbul ilindeki bir ilçe belediyesidir. Araştırmanın evrenini belirlemek için ilk olarak Kamu Görevlileri Etik Kuruluna ulaşılmıştır. Etik kurulu tarafindan etik eğitimleri için öncelikle etik eğiticilerin yetiştirildiğini ve kurumlardan gelen talep üzerine etik eğiticileri tarafından etik eğitimleri verildiği bilgisine ulaşılmıştır. Sonrasında İstanbul'da etik eğitimi veren etik eğiticisi ile irtibata geçilerek düzenli olarak etik eğitimi verilen kamu kurumlarının listesi alınmıştır. Bunlardan birinin belediyeler olduğu öğrenilmiştir. En son ve düzenli eğitimlere gittiği belediyenin ismi alınarak, ilgili belediye ile iletişime geçilmiştir. Ancak söz konusu belediye, isminin kullanılmaması şartıyla çalışmaya katkı sağlayacağını belirtmiştir. Bu nedenle araştırmanın yapıldığı ilçe belediyesinin adı saklı tutulmuştur. İlgili belediyeden düzenledikleri etik eğitimler konusunda ön bilgi alınmıştır.

Söz konusu belediyede bugüne kadar çeşitli bölümlerden seçilen toplamda 250 personele etik eğitimi verilmiştir. Toplamda memur personel sayısı 450 kişiden oluşmaktadır ve tüm personele etik eğitiminin en az bir kere verilmesi amaçlanmaktadır. Bu yüzden 2014' ten itibaren 2018 hariç her yıl etik eğitimleri yapılmıştır ve gelecek eğitim 2019 yılı etik günü olan 25 Mayıs olarak planlanmıştır. Araştırmanın örneklemi ise, belediyede etik eğitimi alan personel arasından tesadüfü yöntem ile seçilen 20 kişidir. 


\subsection{Araştırmada Veri Toplama ve Analiz Yöntemi}

Araştırma nitel bir çalışmadır. Araştırmada "yarı yapılandırılımış mülakat "2" yöntemi kullanılmıştır. Genel hatlarıyla sorular hazırlanmış ve seçilen personelin bilgi ve cevaplarına göre farklı sorular yöneltilerek konu hakkındaki diğer değerle de ulaşılmıştır. Bu sorular sayesinde bir yandan daha fazla bilgi alınırken, bir yandan da örnekler verilmesi sağlanmıştır. Mülakat esnasında sesli kayıt alınmamış, yazılı olarak not tutulmuştur.

Mülakatlar 03 Aralık 2018 - 13 Aralık 2018 tarihleri arasında yapılmıştır. Daha öncesinde belediyeye gidilerek gerekli bilgi verilmiş ve başvuru yapılmıştır. Belediyeden yapılan geri dönüş ile belirlenen gün ve saatte belediyeye gidilerek mülakatlara başlanmıştır. Mülakatlar tamamlandıktan sonra elde edilen veriler, katılımcıdan elde edildiği şekilde değiştirilmeden alıntı şeklinde aktarılan betimsel analiz yöntemi ile analiz edilerek sonuçlar değerlendirilmiştir.

\subsection{Araştırmanın Sınırlılıkları}

$\mathrm{Bu}$ araştırma, kullanılan örneklem ile sınırlıdır. Elde edilen sonuçların ülke bütününe genellenmesi amaçlanmamaktadır. Ayrıca mülakat yapılan personellerin sorulara samimi cevaplar verdikleri varsayılarak değerlendirme yapılmıştır.

\subsection{Araştırmanın Bulguları}

Araştırma sonucunda elde edilen bulgulara yer verilirken ilk olarak araştırmaya katılanlara ilişkin demografik bulgulardan bahsedilecektir. Sonrasında ise elde dilen bulguların etik eğitimiyle ilgili genel bilgilerine, etik eğitimlerinin etik davranışlarının ortaya çıkmasına olan etkisini belirlemeye ve etik eğitiminin etiğe dayalı kurum kültürünün oluşmasına olan etkisini değerlendirmeye yönelik yorum ve değerlendirmeler aktarılacaktır.

\subsubsection{Sosyo-Demografik Bulgular}

Araştırmaya katılan personellerin yaş, unvan ve kaç yıldır kamu görevlisi olarak çalıştığı bilgileri konumuz açısından önem arz etmektedir. Bu kısımda bu bilgiler ele alınacaktır. İlgili bilgiler aşağıdaki tablolarda yer almaktadir.

Tablo1

Araştırmaya Katılan Çalışanların Yaş Gruplarına Göre Dağılımı

\begin{tabular}{|l|l|l|}
\hline Yaş Grubu & Sayı & Yüzde (\%) \\
\hline $18-30$ & 4 & 20 \\
\hline $31-40$ & 8 & 40 \\
\hline $41-50$ & 4 & 20 \\
\hline $51-65$ & 4 & 20 \\
\hline TOPLAM & $\mathbf{2 0}$ & $\mathbf{1 0 0}$ \\
\hline
\end{tabular}

\footnotetext{
${ }^{2}$ Yarı yapılandırılmış mülakat, soruların ana hatlarının oluşturulduğu mülakatın bir türüdür. Görüşmeler esnasında kişinin bilgi ve ilgisine göre yeni soruların sorularak veya belirlenen soruların sorulmayarak konunun farklı boyutları ortaya konulmaya çalışılmaktadır (Al, 2010: 18)
} 
Araştırmaya katılan çalışanların yaş gruplarına göre dağılımı incelendiğinde, çalışanların büyük çoğunluğunun orta yaş olarak nitelendirilen yaş gruplarından oluştuğu, diğer yaş gruplarının eşit dağıldığı dikkati çekmektedir.

Tablo2

Araştırmaya Katılanların Kurumdaki Unvanlarına Göre Dağılımı

\begin{tabular}{|l|l|l|}
\hline Unvan & Sayı & Yüzde (\%) \\
\hline Şef & 3 & 15 \\
\hline Mühendis & 7 & 35 \\
\hline Uzman/ Uzman yardımcısı & 4 & 20 \\
\hline VHKİ & 2 & 10 \\
\hline $\begin{array}{l}\text { Diğer (memur,eğitmen, } \\
\text { telnicuan nromamarı) }\end{array}$ & 4 & 20 \\
\hline TOPLAM & $\mathbf{2 0}$ & $\mathbf{1 0 0}$ \\
\hline
\end{tabular}

Araştırmaya katılan kamu görevlilerinin unvanları incelendiğinde personellerin \%15' i şef, \%15'i uzman, \%5' i uzman yardımcıs1, \%35'i mühendis, \% 10’ u VHKİ (Veri Hazırlama ve Kontrol İşletmeni), $\% 20$ ' si de diğer (memur, eğitmen, teknisyen ve programc1) çalışanlardan oluşmaktadır.

Tablo3

Araştırmaya Katılanların Kurumdaki Çalışma Sürelerine Göre Dağılımı

\begin{tabular}{|l|l|l|}
\hline Çalışma süresi (Yıl) & Sayı & Yüzde (\%) \\
\hline $1-5$ & 6 & 30 \\
\hline $6-10$ & 7 & 35 \\
\hline $11-15$ & 2 & 10 \\
\hline $16-20$ & 1 & 5 \\
\hline $21-30$ & 2 & 10 \\
\hline 31 ve üstü & 2 & 10 \\
\hline TOPLAM & $\mathbf{2 0}$ & $\mathbf{1 0 0}$ \\
\hline
\end{tabular}

Mülakata katılan kamu görevlilerinin çalışma süreleri incelendiğinde \%30' unun 1-5 yıl arası, \%35' i 610 yıl aras1, \%10' u 11-15 yıl arası, \%5' i 16-20 y1l aras1, \%10' u 21-30 y1l aras1 ve \%10' u 31 ve üzeri çalışanlardan oluşmaktadır.

\subsubsection{Etik Eğitimiyle İle İlgili Yapılan Genel Değerlendirmeler}

Belediye çalışanlarına bu başlık altında çeşitli sorular yöneltilmiştir. Öncelikli olarak personellere "Öğrenim hayatınızda (göreve başlamadan önce) etik ile ilgili bir eğitim aldını mı?" sorusu sorulmuştur. Bu soruya cevap veren 20 personelden 13'ü böyle bir eğitim almadıklarını belirtirken, 7 personel etik ile ilgili üniversite dönemlerinde bir ders olarak etik eğitimi aldıklarını söylemişlerdir. 
"Aldiğını etik ĕgitimlerini yeterli ve gerekli buluyor musunuz? Belirli bir sistematiğimi olmall ya da bir kere verilmesi yeterli mi?" sorusu diğer bir sorudur. Kamu görevlilerinin çoğu aldıkları bu eğitimlerin periyodik olmadığını belirtmişlerdir. Dolayısıyla katılımcıların 14' ü verilen etik eğitimlerini de yeterli bulmamaktadır.

"Etik eğitimleri gerekli fakat yeterli değildir. Ĕ̌itimler genel anlamda belirli bir sistematikte devam etmeli. Çünkü yenilenen durumlar sürekli var ve bunlar etik için etkili değişiklikler sağlamakta."

Ancak 6 kişi ise aldıkları etik eğitimlerini yeterli bulmuş ve kendilerine gözle görülür bir katkısı olduğunu söylemişlerdir.

"Eğitimler etik konusundaki bilgi düzeyimi arttırdı bu yüzden yeterliydi diyebilirim. Ayrıca etik konusunun durağan bir şey olmadı̆̆ını düşünüyorum bu yüzden tekrarlanması faydalı olur diye düşünüyorum."

Diğer bir soru ise"Etik eğitimi kimler tarafindan verildi? Ĕgitimi verenlerin yetkin olduğunu düşünüyor musunuz?" ş̧eklindedir. Mülakata katılan personelin çok önemli bir bölümü (16 kişi) etik eğitimi veren kişinin yetkin ve konuya hakim olduğunu düşünürken, 4 katılımcı ise etik eğitimini veren kişinin yetkin olmadığııı düşünmektedir.

"Etik eğitimi veren kişinin yetkin olmadı̆̆ını düşünüyorum. Çünkü akademik bir uzman değildi. Bizim gibi eğitim alan biriydi sanırım. Bu yüzden yeterli olduğunu düşünmüyorum."

Söz konusu eğitimlerde etik kavramı, ahlak-etik, etik mevzuat1, kamuda etik standard1, etik davranış ilkeleri, etik komisyonu, mesleki etik gibi teorik etik anlatılmış ve örnekler verilmiştir. Yöntem olarak ise slayt ve soru cevap yöntemi kullanılmıştır. Genel olarak mülakata katılan belediye çalışanları bu yöntem kullanılarak verilen etik eğitiminin katkı sağladığını söylemiştir.

"Kamu etiği alanında eğitim verildi. Tüm belediye memurlarına yönelik toplu ve sıralı eğitim şeklinde ve katkısı tartışılmaz faydalıydl."

"Kamu kapsamında etik üzerine gerekli olan konulara anlatıldl. Slayt gösterisi ve soru-cevap olarak

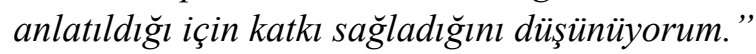

Bu soruya cevap veren 3 katılımcı ise verilen etik eğitiminin katkı sağlamadığını söyleyerek olumsuz bir bakış açısı sergilemişlerdir. Konuya olumsuz yaklaşanlar verilen eğitimin sadece bilgi sahibi yaparak, katkı sağladığı ancak eğitimlerin daha lise çağlarından başlamasının gerekliliği üzerinde durmuşlardır;

Diğer soru "Çevrenizde gördüğ̈̈nüz etik dışı davranışların en önemli sebebinin ne olduğunu düşünüyorsunuz? Sizce mevcut etik eğitimleri ile etik dışı davranışlar ortadan kaldırılabilir mi?" bu soruya araştırmaya katılanlarca çok çeşitli cevaplar verilmiştir. Etik dışı davranışların sebebini eğitimsizlik, kişisel, çıkarcılık, ahlaki eksiklik, söylem ve eylemler arasındaki farklılıklar, aile kaynaklı eksiklikler, aile ve sosyal çevreden gelen baskılar, kişilik özellikleri, çevresel etkiler, genel gidişatın düzensizliği, yükselme hırsı olarak görülmektedir. Ancak araştırmaya katılanların büyük çoğunluğu çevrede görülen etik dışı davranışların en temel sebebinin eğitimsizlik olduğunu belirtmişlerdir. Ayrıca kurumda verilen etik eğitimleri yerine, bu eğitimlerin verilmeye başlandığı yerin aile olmas gerektiği ve sadece belirli bir kurumla bunun kısmen önüne geçilebileceğini düşünmektedirler.

"Etik dışı davranışların bence en önemli sebebi bu konudaki ĕgitim eksikliğidir. Ancak etik değerler bence ailede daha çocukken verilmesi gerekir. Bu bir eğitim işidir. Eğitimde hayat boyudur. Etik eğitimleri etik dışı davranışları tamamen ortadan kaldırır mı bilemem ama olumlu etkisi olur." 
Diğer taraftan katılımcıların çoğunluğu etik dışı davranışların kısmen önüne geçilebileceği üzerinde dururken, 5 katılımcı etik eğitimleri ile etik dışı davranışların kaldırılamayacağını düşünmektedir. Çünkü, ilgili katılımcılar etik dışı davranışların asıl sebebini karakter olarak açıklamaktadır. Bu yüzden de sadece kurum içinde verilen eğitimlerle etik dışı davranışların önlenemeyeceğini düşünmektedirler. 1 katılımcı ise siyasi ilişkilerden dolayı etik dışı davranışların ortadan kaldırılamayacağını söylemektedir.

Sonuç olarak, etik eğitimleri ile etik dışı davranışların önüne geçilmesi yönündeki soruya verilen olumlu ve olumsuz cevaplara göre, etik dışı davranışların temeli eğitimsizliktir. Ancak katılımcılar, bu eğitimlerin kurumlarda verilerek geç kalındığı, aileden başlaması gerektiği fikrini sunmuşlardır. Burada da etik dışı davranışların sebebini karakter olarak açıklayanlar ön plana çıkmaktadır. Dolayısıyla katılımcılara göre çevrede görülen etik dışı davranışların öne çıkan iki sebebi vardır.

"Sizce etik ögretilebilir bir şey mi? (evet: Öleyse özel bir ĕgitim mi gereklidir ya da etiğe dayalı bir kurum kültürünün yerleşmiş olduğu bir kurumda çalışmak bu anlayışı benimsemek için yeterli midir?)" katılımcılara yöneltilen diğer sorudur. 17 katılımcı etiğin öğretilebilir bir şey olduğunu söylerken, 1 katılımcı kısmen öğretilebilir ve 2 katılımcı ise öğretilemez olduğunu düşünmektedir. Etiğin öğretilebilir bir şey olduğunu düşünen katılımcılar etiğe dayalı kurum kültürünün olduğu kurumlarda görev yapmanın önemi üzerinde dururken, periyodik olarak da özel etik eğitimlerinin gerekli olduğunu söylemektedir;

"Etik hem ögrrenilebilir hem de ögretilebilir bir şeydir. Özel bir ĕgitim daha iyi olur mu bilmiyorum. Ancak normal eğitimle yeri ve zamanı geldiğinde etikten bahsedilmesi ve etik olunmadı̆̆ında karşılaşılan sorunların örneklendirilerek açıklanması etkili olur. Ayrıca çalışılan kurum da önemlidir. Çünkü etik kültürünün yerleşmiş olduğu bir kurum bu anlayışı benimsemede yardımcı olur."

"Evet etik ögrretilebilir bir şeydir. Etiğe dayalı bir kurum kültürü de çok önemlidir. Ancak etik ögretmek veya ögrenmek için yeterli değildir. Bu anlayışı benimsemek için eğitim almak destekleyici olur."

5 katılımcı ise, etiğin öğretilebileceğini ancak bunun kurumda değil de, daha küçük yaşlardan başlanarak bir kültür haline dönüştürülmesi ve böylece toplumda bir etik kültürün yerleşmesinin gerekliliğinin önemi üzerinde durmuştur. Dolayısıyla etiğin öğretilebileceğini ancak bunun bir yandan etiğe dayalı bir kurum kültürünün olduğu kurumda görev yaparak bir yandan da yine periyodik olarak etik eğitimleriyle desteklenmesiyle daha verimli olacağı sonucuna varılmaktadır. Ancak önemli nokta yine etik eğitimlerinin verilmeye başlandığg kurumun aile olmasının gerekliliğidir.

Bu bölümde son soru olarak "Etik eğitimi mümkün müdür? Sizce etik eğitimleri nasıl olmalıdır?" soruları sorulmuştur. Etik eğitiminin mümkün olup olmadığı sorusuna 19 katılımcı etik eğitiminin mümkün olduğunu söylemiştir. Etik eğitimlerinin nasıl olması konusunda ise farklı öneriler sunulmuştur. Burada da öne çıkan konulardan biri etik eğitimlerinin verilmeye başlandığı yer ve yaştır. Birçok katılımcıya göre, etik eğitimlerinin kurumlarda verilmeye başlanması etik konusunda bir farkındalık yaratmaktadır. Ancak bu yeterli olmamaktadır. Bu yüzden etik eğitimleri ailede başlamalıdır. Sadece bir katılımc1 ise "etik eğitimi mümkün olsa bile verimliliği tartışmalıdır" demiştir.

\subsubsection{Etik Eğitimlerinin Etik Davranışların Ortaya Çıkmasına Olan Etkisine İlişkin Değerlendirmeler}

Mülakata katılan kamu görevlilerine, aldıkları etik eğitimlerinin, görevlerini yerine getirirken onlara nasıl bir katkı sağladığını tespit edebilmek amacıyla 6 soru yöneltilmiştir. Bu sorular Pimple' nin tanımladığı etik eğitimlerinde etik davranışların ortaya çıkmasında gerekli olan dört farklı psikolojik süreç dikkate alınarak hazırlanmıştır. Bu süreçler etik duyarlılık, etik muhakeme, etik bağl1lık ve etik kararl11ıtır (Aktaran Aydın, 2016a: 226-227). 
İlk olarak katılımcılara "Almış olduğunuz etik eğitimi etik konularına iliş̧kin bir farkındalık yarattı mı? (yani daha önce sorun olarak görmediğiniz durumları sorun olarak görmeye başladınız mı?)” sorusu sorulmuştur. Mülakata katılan katılımcılardan 14' ü aldıkları etik eğitimlerinin etik konusunda bir farkındalık yarattığını, farkı bakış açıları edindiklerini, çevrelerinde olanları anlamlandırabildiklerini söylemişlerdir.

"Etik eğitimi etik konularına ilişkin bir farkındalık yarattı. Çevremdeki olayların farkına vardım. Sorun olmayan bir durumun sorun oluşturabileceğini öğrendim. Örneğin, hediye alma konusu. Önceden hediye alma konusunda bir sorun görmezken eğitimden sonra alınan hediyenin ne amaçla verildiğinin, boyutunun, değerinin de önemli olduğunun farkına vardım."

6 katılımcı ise almış oldukları etik eğitiminin etik konularına ilişkin herhangi bir farkındalık yaratmadığını söylemiştir. Buradaki dikkat çeken nokta ise aldıkları etik eğitiminin farkındalık yaratmadığını söyleyen katılımcıların hepsi öğrenim hayatlarında etikle ilgili herhangi bir etik eğitimi almayan belediye görevlileridir.

Diğer soru "Görevinizi yerine getirirken etik ikilemlerle karşılaşıyor musunuz? En çok karşılaştığınız etik ikilimler nelerdir? Örnek verebilir misiniz?” Mülakata katılan söz konusu katılımcılardan 9' u görevlerini yerine getirmeleri esnasında etik ikilemlerle karşılaştıklarını ve bunların, yasalar ve etik konusunda sık sık karşı karşıya gelmeleri, etik dışı olan bir şeyin emredilince yapılmak zorunda kalınması, tanıdığa gösterilen ayrıcalıklar, verilen hediyeleri alıp almamak şeklinde örnekler vermişlerdir;

"Evet karşılaşlyoruz. Belediyeler kalabalık ve iş yaptırmak belli prosedürlere tabi. Bu yüzden vatandaşlar için bir tanıdıklarının olması büyük avantaj sağlamaktadır. Personeller de bir yandan etik dışı olmasına rağmen tanıdıklara ayrıcalıklar gösterip göstermeme konusunda ikileme düşmektedir. Çünkü etik konusundaki bilince sahip olmayan vatandaşlar bunu normal karşılamakta ve talepte bulunmaktadir. Personeller ise yardımcı olmasa söz konusu vatandaş tarafindan ayıplanmakta, yardımcı olsa etiğe aykırıdır. Böylece personeller tanıdık, akraba vs. olması sebebiyle nasıl davranmaları gerektiğini bilememektedir."

10 katılımcı ise etik ikilemlerle karşılaşmadıklarını, 1 katılımcı da nadiren karşıllaştı̆̆ını ancak siyasi ve yönetimsel baskı olmasına rağmen çizgisinden ve etik kurallardan dışarı çıkmadığını söylemiştir.

Üçüncü soru ise almış oldukları etik eğitiminin çevrelerinde yaşanan etik ikilemleri fark edebilmelerini sağlayıp sağlamadığına yöneliktir. 14 katılımcı etik ikilemleri fark edebilmelerini sağladığını, 1 personel çokça değil derken, 5 katılımcı etik eğitimlerinin bu yönde bir fark yaratmadığını söylemiştir. Ancak fark yaratmadığını söyleyen bu 5 katılımcı zaten etik ikilemleri fark edebildiklerini bu yüzden eğitimin bir katkısının olmadığını düşünmektedir.

Dördüncü soruda "Almış olduğunuz etik eğitimi karşılaşmış olduğunuz etik ikilemleri çözmede size kllavuzluk etti mi?" şeklindedir. Bu soruya araştırmaya katılanlar farklı cevaplar vermişlerdir. 12 katılımcı kılavuzluk ettiğini ifade ederken, 4 katılımcı kılavuzluk etmediğini, 2 katılımcı kısmen kılavuzluk ettiğini, 2 katılımcı ise etik ikilemlerle karşılaşmadıklarını belirtmişlerdir.

"Almış olduğum etik eğitimi etik ikilemleri çözmede klsmen kılavuzluk etti ama yeterli değil. Çünkü etik eğitimi bir süreçtir ve aldığımı eğitimler periyodik olmadı̆̆ için zamanla unutulmaktadır."

"Hayır kllavuzluk etmedi. Çünkü çoğu etik ikilemde karar mercii ben değilim. Örneğin bazen etik dışı bir durum söz konusu olur ve amiriniz yapmanızı söyler. Dolayıslyla bir ikilem yaşarsınız ancak etik dışı olduğunu bildiğiniz halde emredildiği için yapak zorunda kalırsınız."

Beşinci soru "Etik ikilemlerle karşılaştı̆̆ınızda etik olanı tercih etmeme yönünde çevrenizde baskı gördünüz mü? Bu kararınızı etkiledi mi?" 16 katılımcı çevrelerinden etik olmayanı yapmaları 
konusunda böyle bir baskı görmediklerini söylemişlerdir. Bazı katılımcılar ise, bir baskıya maruz kalırlarsa etkilenmeyeceklerini, buna müsaade etmeyeceklerini belirtmişlerdir.

4 katılımcı ise çevrelerinden bu konuda baskı gördüklerini ancak kararlarını etkilemediğini söylemiştir.

"Toplumsal baskı diye bir şey var elbette ama kendi bildiğini ve karşındakinin bilmediğini görünce kararı etkilemiyor tabii. Örnek vermek gerekirse akraba, komşu, hemşehri vb. yakınlardan gelen talepler... Yapıldı̆̆ında etik dışı yapılmadı̆̆ında toplumsal bir ayıplama ve dolayısıyla da toplumsal baskiya sebep olabilmektedir."

Katılımcıların bu soruya verdikleri cevaplar değerlendirildiğinde, etik ikilemlerle karşılaşmaları veya karşılaşmamaları verecekleri kararlar doğrultusunda, çevrelerinden bir baskı olsun ya da olmasın kararlarını etkilememektedir.

Bu bölümdeki son soru ise "Görev esnasında sizi etik dışı davranmaya iten nedenler var mı? Varsa nelerdir? Böyle bir durumda etik olan tercih etmede kararlılık gösteriyor musunuz?”. Bu soruya 10 katılımcı etik dışı davranmaya iten nedenlerle karşılaşabildiklerini söylemişlerdir.

"Her işse olduğu gibi olması gerekenin dişında tabiî ki istekler olabiliyor. Yalnız yönetmelik ve kanunlar açık. Meslek etiğine uymak öncelikle vicdani bir sorumluluk. O yüzden kararlılık gösteriyorum."

10 katılımcı ise etik dışı davranmaya iten nedenlerle karşılaşmadıklarını ancak etik olanı tercik etmede kararlı davrandıklarını söylemişlerdir.

\subsubsection{Etik Eğitiminin Etiğe Dayalı Kurum Kültürünün Oluşmasına Olan Etkisinin Değerlendirilmesi}

$\mathrm{Bu}$ bölümde ilgili belediye çalışanlarına 2 soru sorulmuştur ve etik eğitiminin kurum kültürünün oluşmasına olan etkisinin değerlendirilmesi amaçlanmıştır. İlk soru katılımcıların aldıkları etik eğitimlerinin etik değerlere dayalı bir kurum kültürünün oluşmasına olan etkisinin değerlendirilmesidir. 5 katılımcı dikkate değer ölçüde bir katkısının olmadığını, bir temel üzerine verilmesi gerektiğini, kurum kültürünün kişilerden bağımsız olması gerektiği fakat ülkemizde devlet kurumlarının şahsi tercihlere göre idare edildiği için kurum kültürünün oluşamayacağı, verilen eğitimlerin kişisel olarak etkilediği, kurum olarak çok fazla etkisinin olmadığını belirtmişlerdir.

"Etik eğitimleri bir temel üzerine ve profesyonel manada yetkin kişilerce verilmeli ki etik değerlere dayalı kurum kültürü oluşabilsin."

"Kurum kültürü kişilerden bağımsız olmalıdır. Ama ülkemizde devlet kurumları şahsi tercihlere göre idare edildiği için etiğe dayalı bir kurum kültürünün oluşması şimdilik mümkün değil."

14 katılımcı ise, etiğe dayalı bir kurum kültürünün oluşmasına katkısının olduğunu, farkındalığı arttırdığını, bilgi amaçlı (etik davranış ilkelerini hatırlatmak), kamu zararı ve personel sorumlulukları açısından, kararlı bir tutum oluşturmada, objektiflik, mesleğine ve kuruma saygı, sistemleşme, kurum hizmeti sınırları, kendi sorumlulukları, etik değerlendirmede, ayrım yapmama, empati gibi konularda katk1 sağladığını söylemiştir. Ancak üzerinde durulan nokta etiğin sonradan edinilmesi zor bir değer olduğu, bu nedenle çocukken edinilmeye başlanmasının gerekliliğidir.

İkinci soru ise "Etiğe dayalı bir kurum kültürü oluşturulmasında birinci dereceden önemli faktör sizce nedir?". Burada büyük çoğunluğun hemfikir olduğu faktör eğitimdir. Yine hemfikir olunan nokta bu eğitimlerin sonradan değil de aileden verilmeye başlanmasıdır.

"Bana göre bir insanın yetişmesiyle, ailede gördü̈̆̈̈ eğitim başta olmak üzere, çevre ve okulda gördükleriyle ilgili daha çok. Etik eğitimi destekleyici olur sadece. Bu düşüncedeyim."

\section{Sonuç ve Değerlendirme}


Etik, genel iyi ve doğru davranış kurallarıdır. Etik davranış, bireylerin sahip olduğu değer, tutum, davranış ve bilgiden oluşmaktadır. Etik dışı davranış ise, bireylerin sahip olduğu bilgisizlik olarak öne çıkmaktadır. Bu bilgisizliğin önüne geçmenin ön koşulu ise etik eğitimidir. Etik eğitimi kamu görevlilerine etik ilke ve değerler konusunda bilgi vermektedir. Ayrıca etik eğitimleri sadece kuralları tekrar etmenin çok ötesinde olup, amacı etik davranış konusunda farkındalık oluşturularak davranışa dönüştürülmesinin sağlanmasıdır.

Kamu personelinin görevleri, yetkileri ve sorumlulukları açıkça tanımlanmış olmasına rağmen, personeller kamu görevlerini yerine getirdikleri esnada çeşitli durumlarla karşılaşabilmektedirler. Bazen kişisel baskılar, bazen siyasal baskılar, bazen de ikilemler etik dışı davranmaya itebilmekte ya da savunmasız kalabilmektedir. Çünkü etik ömür boyu süren bir faaliyet değildir. Bu yüzden sistematik ve planlı etik eğitimleri kamu kurumları için temel olmalıdır. Etik eğitimleri sayesinde böylece kamu personelinde bir farkındalık oluşmakta ve davranışa dönüşerek kamu kurumlarında etiğe dayalı bir kurum kültürü oluşmaktadır. Dolayısıyla kamu yönetiminde etiğin öğrenilmesi, benimsenmesi, içselleştirilmesi ve davranışa dönüştürülerek etiğe dayalı bir kurum kültürünün oluşturulması bir süreçtir. Bu süreç etik eğitimleri ile sağlanmaktadır.

Etik eğitimleri kamu görevlilerinin etik ilke ve değerleri benimsemesine olan katkısının değerlendirilmesi amacıyla İstanbul'un bir ilçe belediyesinde yarı yapılandırılmış mülakat yöntemi ile yapmış olduğumuz araştırmada elde ettiğimiz sonuçları 3 bölümde değerlendirebiliriz.

İlki etik eğitimine ilişkin değerlendirmelerdir. Söz konusu belediyede mülakata katılan personelin çok az bir kısmının öğrenim hayatlarında etik eğitimi aldığı görülmüştür. Yapılan eğitimlerde her belediye çalışanının etik eğitimi alması amaçlanmakta olup etik eğitimleri düzenlenmektedir. Ancak personelin etik eğitimi alması amaçlanmasına rağmen personelin çoğuna göre periyodik bir eğitim yoktur. $\mathrm{Bu}$ yüzden katılımcılar aldıkları eğitimleri gerekli görmelerine rağmen yeterli bulmamaktadırlar. Çok az bir kısmı ise aldıkları eğitimlerin gözle görülür bir etkisinin olduğunu ve yeterli bulduklarını söylemişlerdir. Öne çıkan nokta ise etik eğitiminin gerekliliği ve bir sistematiğinin olmasının önemi olmuştur. Katılımcılar verilen eğitimlerin de genel olarak katkı sağladığ düşünen kişiler bu eğitimlerin daha lise çağlarında başlamasının gerekliliği üzerinde durmuşlardır.

$\mathrm{Bu}$ bölümde dikkati çeken diğer bir nokta ise belediye çalışanlarının çevrelerinde gördükleri etik dışı davranışların sebebi üzerinedir. Bu konuda farklı cevaplar alınmıştır. Ancak çoğunluğu eğitimsizlik üzerinde durmuştur. Ayrıca katılımcıların çoğu kısmen geçilebileceğini söylerken, \%25'i (5 katılımcı) etik dışı davranışların sebebinin karakter olduğu ve bu yüzden mevcut etik eğitimleriyle ortadan kaldırılamayacağını söylemiştir. İki taraf için de ortak sonuç ise etik eğitimlerinin aileden başlamasının gerekliğidir. Çünkü katılımcıların büyük çoğunluğuna göre etik öğretilebilir bir şeydir ve etik eğitimleri mümkündür. Dikkat çeken nokta ise bu eğitimlerin başladığı yerin aile olmasının önemidir. Eğer bu eğitimler aileden başlarsa hem birey olarak hem kurum olarak hem de toplum olarak bir etik kültür oluşabilir sonucuna ulaşılmıştır.

İkincisi etik eğitimlerinin etik davranışın ortaya çıkmasına etkisini belirlemeye yönelik değerlendirmelerdir. Bu kısımda katılımcıların çoğu aldıkları etik eğitimlerinin etik konusunda bir farkındalık yarattığını farklı bakış açıları oluşturduğunu ve çevrelerinde olup biteni anlamlandırabildiklerini söylemişlerdir. Bu katılımcıların neredeyse yarısı görevlerini yerine getirmeleri esnasında etik ikilemlerle karşılaştıklarını söylemişlerdir. Bu ikilemler yasalarla etiğin çelişmesi, etik dışı olan bir şeyin emredilince yapılmak zorunda kalınması, tanıdığa gösterilen ayrıcalıklar, verilen hediyeleri alıp almamak şeklinde ortaya çıkmaktadır. Ancak burada dikkat çeken nokta vatandaş boyutu olmuştur. Çünkü katılımcı ne kadar etik davranmaya çalışsa da vatandaşlar için işlerinin hızlı ve sorunsuz olmasında bir tanıdık, eş ya da dostlarının olması avantaj olarak görülmekte ve ayrıcalık talebinde bulunulmaktadır. Bu da katılımcılarda da bir ikilem oluşturmaktadır. Dolayısıyla sadece belediye çalışanına verilen etik eğitiminin etik bir bilinç oluşturmak için yeterli olmadığı söylenebilir. 
Son olarak, etik eğitiminin etiğe dayalı kurum kültürünün oluşmasına olan etkisine yönelik değerlendirilmeler yapılabilir. Bu bölümde olumsuz gelen cevaplara rağmen katılımcıların çoğu etiğe dayalı bir kurum kültürü oluşturmada birinci faktör olarak eğitimi görmüştür ve etik eğitiminin etiğe dayalı bir kurum kültürü oluşturmada katkısının olduğunu yönündedir. Ancak dikkat çeken nokta yine etik eğitimlerinin aileden başlamasının önemidir.

Elde etmiş olduğumuz sonuçları genel olarak değerlendirdiğimizde söz konusu belediyede her personelin etik eğitimi alması amaçlanmasına rağmen katılımcılara göre periyodik bir eğitim yoktur. Ancak verilen etik eğitimlerinin gözle görülür bir katkısı olduğu görülmektedir. Çünkü etik eğitimlerinin en önemli amacı, etik konusunda farkındalık oluşturmaktır. Katılımcılardan alınan cevaplara göre de verilen etik eğitimleri onlarda bir farkındalık oluşturmuş ve çevrelerinde yaşanan etik ikilemleri de fark edebilmeleri konusunda yol göstermektedir. Ayrıca \% 50 oranında katılımcıların etik olanı tercih etme konusunda da kararlılık sağladığı, diğer \%50'sinin de zaten etik dışı davranmaya iten bir nedenle karşılaşmadığı görülmüştür. Böylece belediye personeline etik davranma konusunda yol gösteren ve kılavuzluk eden etik eğitimlerinin büyük oranda da kamu personeline ve kuruma katkı sağladığı açıktır. Bunu oluşturmada da birinci dereceden önemli faktör eğitimdir. Bu etik eğitimlerinin de verilmeye başlandığı yer aile olmalıdır. Çünkü etik konusunun vatandaş boyutu da son derece önemlidir. Eğer etik eğitimleri aileden verilmeye başlanırsa hem bireysel hem kurumsal hem de toplumsal anlamda bir etik bilinç, farkındalık oluşturulabilir ve böylece içselleştirilerek davranışa dönüştürülebilir. 


\section{Kaynakça}

Aydın, İnayet (2016a), “Akademik Etik”, Pegem Akademi, Ankara.

Aydın, İnayet (2016b), "Yönetsel, Mesleki ve Örgütsel Etik”, Pegem Akademi, 7. Baskı, Ankara.

Alıcı, Orhan Veli, (t.y), "Kamu Görevlileri Etik Kurulu ve Davranış İlkeleri”, ss.65-73. (https://studylibtr.com/doc/1188366/kamu-g\%C3\%B6revlileri-etik-kurulu-ve-etik-

davran\%C4\%B1\%C5\%9F-i\%CC\%871keleri /), 03.03.2019

Bayar, Yavuz (1979), “Türk Kamu Yönetiminde Rüşvet”, Amme İdaresi Dergisi, Cilt: 12, Sayı:3, ss.3952.

Cevizci, Ahmet (2016), “Uygulamalı Etik”, 2. Bask1, Say Yayınları, İstanbul.

Cooper, Terry L. (2001), "The Emergence of Administrative Ethics as a Field of Study in the United States", Handbook of Administrative Ethics, edition: 2, Macker Dekker Inc., Newyork pp. 1-36.

Demiral, Berkan, Nalan Demiral (2007), "Kamu Yönetiminde Etik Eğitiminin Önemi”, Kamu Yönetimi Yöntem ve Sorunlar, Ed. Şinasi Aksoy ve Yılmaz Üstüner, Nobel Yayın Dağıtım, İstanbul.

Ekins, April Hejka (1998), “Teaching Ethics Across The Public Administration Curriculum”, Journal of Public Affairs Education, vol: 4, no: 1, pp.45-50.

Eryılmaz, Bilal (2012), Kamu Yönetimi, Umuttepe Yayınları, Kocaeli.

Gökdayı, İsmail (1998), "Yozlaşan Kamu Yönetimi'nde Etik İkilemler, İlkeler ve Etik Kültürü”, Siyasette ve Yönetimde Etik Sempozyumu Bildirileri 24-26 Aralık, Yay. Haz. Mustafa Lütfi Şen, Özer Köseoğlu, Hale Biricikoğlu ve Fatma Yurttaş, Bilge Matbaacılık, Sakarya.

Haynes, Felicity (2014), "Eğitimde Etik”, 2. Baskı, Çev. Semra Kunt Akbaş, Ayrıntı Yayınları, İstanbul.

Ilgaz, Selçuk, Türkan Bilgili (2006), "Eğitim ve Öğretimde Etik”, Dergipark-Atatürk Üniversitesi Kazım Karabekir Eğitim Fakültesi Dergisi, Cilt:0, Y1l: Ocak, Sayı: 14, ss. 199-210.

Kutlu, Hüseyin Ali (2008), "Muhasebe Meslek Mensupları ve Çalışanlarının Etik İkilemleri: Kars ve Erzurum İllerinde Bir Araştırma”, Ankara Üniversitesi SBF Dergisi, 63-2, ss: 143-170.

Lewis, Carol W. ve Stuart C. Gilman, (2005), "The Ethics Challenge in Public Service: A ProblemSolving Guide, Wiley, 2nd. Edition, ss.1-363.

Menzel, Donald C., (2001), "Ethics Management in Public Organizations: What, Why and How?" Handbook of Administrative Ethics, edition: 2, Macker Dekker Inc., Newyork, pp. 355-365.

Nohutçu, Ahmet (2004), “Etik ve Kamu Yönetimi”, Çağdaş Kamu Yönetimi II, Ed. Muhittin Acar ve Hüseyin Özgür, Nobel Yayın Dağıtım, Ankara.

Özsemerci, Kemal (2005), “Türk Kamu Yönetiminde Yolsuzluk ve Yozlaşmanın Kültürel Alt Yapısı”, Sayıştay Dergisi, Temmuz-Eylül 2005, Sayı: 58, ss. 3-20.

Önen, Mustafa, Ali Yıldırım (2014), "Kamu Yönetiminde Etik Denetimi”, Akademik Yaklaşımlar Dergisi, Bahar 2014, Cilt:5, Say1:1, ss. 103-126.

Pieper, Annemarie (2012), "Etiğe Giriş", 2. Baskı, Çev. Veysel Atayman ve Gönül Sezer, Ayrıntı Yayınları, İstanbul.

Starc, Mario, (2017), "Ethics and the Ethical Attitude", Jung Journal: Culture \& Psyche, Winter, Vol: 11: No: 1, pp. 47-52. 
Şen, Mustafa Lütfi (2005), "Kamu Görevlilerini Yoldan Çıkaran Bubi Tuzakları: Hediye ve Kişisel Kullanım Amacıyla Yapılan Bağışlar", Siyasette ve Yönetimde Etik Sempozum Bildirileri 18-19 Kasım 2005, Yay. Haz. Mustafa Lütfi Şen, Özer Köseoğlu, Hale Biricikoğlu ve Fatma Yurttaş, Bilge Matbaacilık, Sakarya.

Şen, Mustafa (2012), Kamu Görevlileri Etik Rehberi, 3. Basım, Nisan 2012, Ankara.

Tepe, Harun (2011), "Etik ve Metaetik”, 2. Bask1, Türkiye Felsefe Kurumu, Ankara.

TÜSİAD, (2003), "Kamu Hizmetinde Etik: Güncel Konular ve Uygulama", TÜSİAD Eylül 2003, İstanbul.

TÜSİAD, (2005), “Devlet’te Etikten Etik Devlete: Kamu Yönetiminde Etik”, Kavramsal Çerçeve ve Uluslararası Uygulamalar, 1. Cilt, İstanbul, Kasım 2005.

Yatkın, Ahmet (2015), “Kamuda Etik Yönetimi”, Nobel Akademik Yayıncılık, Ankara.

Yüksel, Cüneyt (2010), Devlette Etik: Dünyada ve Türkiye’ de Kamu Yönetiminde Etik, Yasal Altyap1 ve Uluslar Arası Uygulamalar, Boğaziçi Üniversitesi Yayınevi, İstanbul.

http://www.gazetebilkent.com/2014/10/19/watergate-skandali-ve-nixonin-cokusu/, 29.04.2019.

Uluslararası Şeffaflık Derneği (2017), http://www.seffaflik.org/cpi2017/ , 10.03.2018.

Kamu Görevlileri Etik Kurulu (2017), http://www.etik.gov.tr/yayinlar/, 13.10.2017.

Kamu Görevlileri Etik Kurulu (2017), 2016 Faaliyet Raporu, Kamu Görevlileri Etik Kurulu, Ankara, 2016, www.etik.gov.tr/faaliyet raporu, 04.01.2018.

5176 sayılı Kamu Görevlileri Etik Kurulu kurulması ve Bazı Kanunlarda Değişiklik Yapılması Hakkında Kanun (2004), TC. Resmi Gazete, 25486, 08.06.2004.

Kamu Görevlileri Etik Davranış İlkeleri ile Başvuru Usul ve Esasları Hakkında Yönetmelik (2005), TC. Resmi Gazete, 25785, 13.04.2005. 